\title{
Graphics in History: An Examination of Visuals in Counter-Reformation Art
}

\author{
Somanand Saraswati and Urmi Satyan \\ School of Liberal Studies, Pandit Deendayal Energy University, \\ Raisan, Gandhinagar-382 007 Gujarat, India \\ Corresponding author email: somanandsaraswati@gmail.com
}

\begin{abstract}
The concept of patronage has stayed in society in every era, and great artists were able to make spectacular creations because they had patronage. These sponsorships by kings, popes, and the wealthy people played a multi-dimensional role in society. It did promote art, but it also promoted something 'else'. Because Visual art is something which has an impact on people, even those who are illiterate, that's why it is 'used' for by certain people. The paper examines the concept of patronage in different periods, and focuses on who were patronizing, and most importantly, why they were giving the support.
\end{abstract}

KEY WORDS: COUNTER-REFORMATION, PATRONAGE, RENAISSANCE, ART.

\section{INTRODUCTION}

'Patronage' has always played an essential role in society. It has the power to set the course of any form of art. In visual art, both the style and content of an era was largely determined by the way commissions are given. In Italian, patronage of the arts is called mecenatismo. It is also known as clientelismo, as it refers to the relationship between a patron and his client. Although these 'Patronage' are full of political, religious economic and social motives, still it is only because of 'Patronage' that the great Artist and their art flourished. William Roscoe believes that patronage plays two impotent roles 'encouragement' and 'protection'; but it is also a fact that it is used as a political and religious tool. The question of artistic freedom also comes with patronage. Its effect on mankind is immense, as scholars believes that visual art affects the emotional and subconscious mind.

The Baroque art and Counter-Reformation: The baroque art is the perfect period to understand how the patronage works. There were many motives hidden in

Biosc Biotech Res Comm P-ISSN: 0974-6455 E-ISSN: 2321-4007

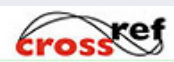

Identifiers and Pagination

Year: 2021 Vol: 14 No (5) Special Issue

Pages: $352-354$

This is an open access article under Creative

Commons License Attribn 4.0 Intl (CC-BY). DOI: $h t t p: / / d x$.doi.org/10.21786/bbrc/14.5/60 the commissioning of art work. During the course of time, churches became corrupt and the centre of political power. In reaction, reformers like Martin Luther raised their voice and wrote against the Catholic Corruption and Catholic ideology, especially by writing pamphlets, like Martin Luther's Ninety-Five Theses. It is a movement known as Protestantism. They tried to fill the gap that Catholic churches had made between God and people. Catholic churches tried their best to stop, and they became inhuman (Rubinstein 1988). People were killed in the most barbaric way, like burning alive that too in public. A major figure in the Protestant movement, William Tyndale, who translated the Bible into English, was burnt alive. An account of such inhuman events was published by John Day in 1563. The Actes and Monuments (Book of Martyrs) is a book by John Foxe that shows the people's lives, sufferings by Church and brutal deaths.

Such event helped to raise the consciousness in common public, and people in Catholic churches started to have reform in them, which is known as the Counter Reformation. It was a Catholic's answer to the Protestant movement. They tried to fill the gap between God and people in a way in which Catholic churches do not lose their power, that is through art. Art is a powerful medium, and Catholic churches know that art is something that gives more impact than writing. Also, people of that era were not educated, so art was something that could even be understood by illiterate. So a Council of Trent was established in 1545, which took decisions regarding
Article Information

Received: $28^{\text {th }}$ Mar 2021 ccepted after revision: 27th May 2021 
visual arts. Baroque realistic art became a mean of propaganda for the Roman Catholic church because they were sponsoring it.

This shows the power of patronage that could change the style of an era. There were still religious Madonna, nativities, and crucifixions, but they are quite different from those of the previous Ages. Now they do not look divine or heavenly with a golden aura but look just like one of us. Rookmaaker (1985) writes that "The artists of the Reformation painted life and the world realistically, without idealizing or glorifying the creature but, instead, showing things as they really were and are, not glossing over sin but not exalting it either" Francis Schaeffer (1986) states,"At its core, therefore, the Reformation was the removing of the humanistic distortions which had entered the church" For example; Caravaggio's Crucifixion of St. Peter, (1601) or The Supper at Emmaus, (1600) (Figure 1 and 2 respectively).

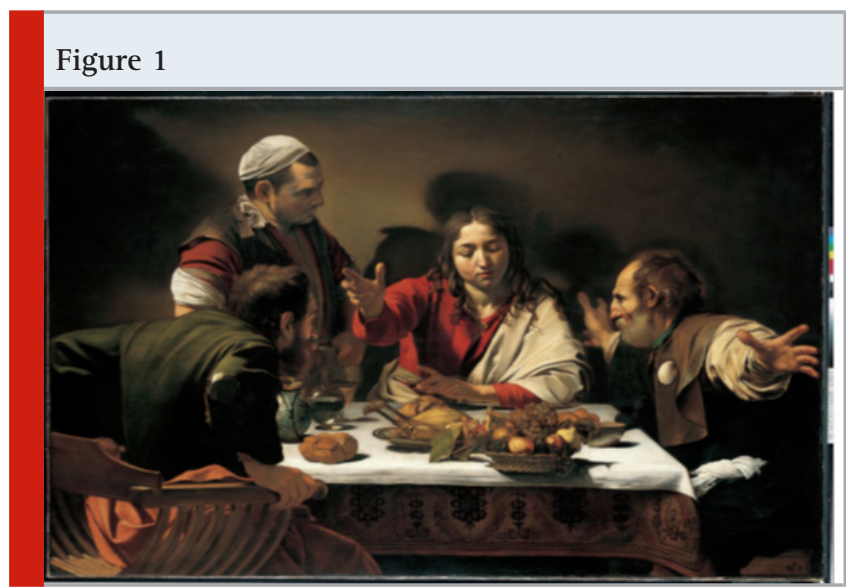

Figure 2

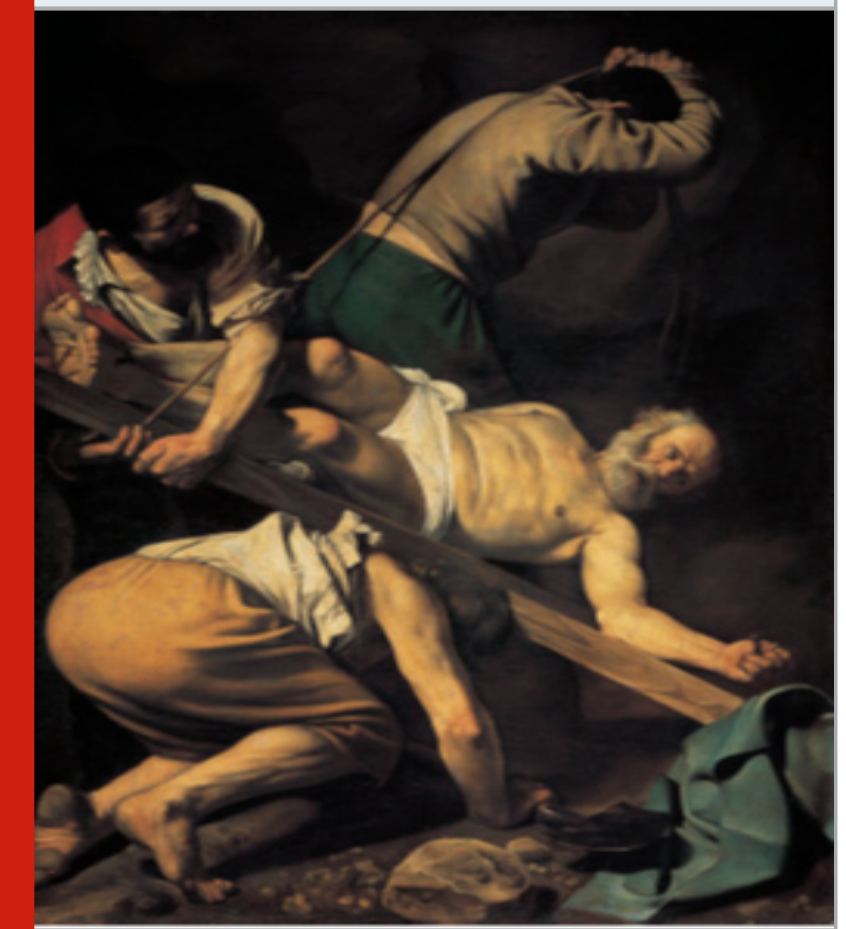

The Baroque art in Protestant countries: The Protestant art was largely destroyed during the movement. It later survived in the Protestant countries. Protestant artists and their patrons were looking towards art differently. Patrons were wealthy individuals who gave money for, landscapes scenes, portraits of life. For example, the famous picture of Protestant Bishop John Hooper's execution. Many critics believe that Vermeer's The Milkmaid (1658-60) shows the Protestant virtue and pious living. (figure 3) There is an interesting area of patronage which is related to non-religious art works. It sounds strange to many if we study the taste of the middle class of Holland. They sponsor for such art work which they can use to decorate their homes, painting with their own pictures. Moreover, picture of thing they wanted to do in their life or have done. The Northern Europe including Dutch was free and wealthy middle class. Here art was not controlled by Popes or monarchs. So, with the use of amazing light effects and latest technologies like camera obscora, Artists like Vermeer were able to create art work without religious influence. For example, Officer and a Laughing Girl by Vermeer. Another example of individual patronage is when Captain Frans Banninck Cocq commissioned Rembrandt to make his Militia Company's group portrait.

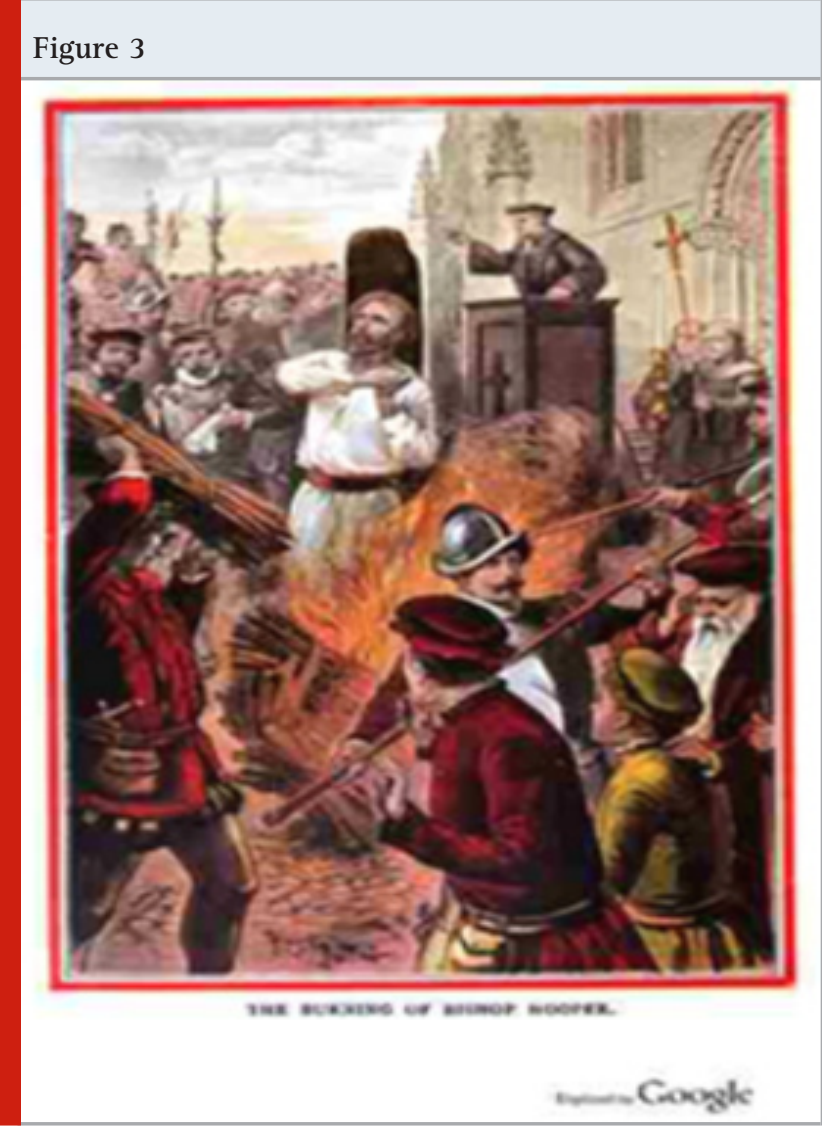

Royal patronage is an exciting area to explore. Kings and rulers have always been the most prominent and most influential patronage in every era. Even in the period of before Christ, Horace wrote about the importance of the patronage. In France, King Louis XIV established French Royal Academy of Fine Arts. With this, he tried 
to control the art work in France. He started sponsoring the painting through his Royal Academy. It was another type of propaganda, not of God but of a King. All art work sponsored by the academy, would be known as Academic painting. For Example; Rigaud's painting of Louis XIV, 1701.

High renaissance is one of the best eras to be examined in terms of patronage. It widely accepted that the three significant figures of High renaissance are Da Vinci Michelangelo and Raphael. Michelangelo is a legend who is known for his extraordinary art work. However, more interestingly the stories of commissions are as fascinating as his artwork. His every art work has an exciting story of patronage. Michelangelo was quite young (only 26 years) and he had to convince the Opera that he can make it so he should be given the commission. Michelangelo got the commission on 16 August 1501. The commission of David had a political intention. The city of Florence was going through a bad time; it was weak and lost the wars. Ordinary citizens were under pressure of taxes. Political power wanted to revive the spirit of the city by making a symbol of pride. It is another kind of Political Patronage which is different from Royal Patronage, which was discussed earlier.

Julius is known for his religious patronage. Many of the famous art work that we know as High Renaissance art was commissioned by him, that's why is known as "the Renaissance Pope". He commissioned a lot of art works to various people. He commissioned Michelangelo for the painting of the Sistine Chapel ceiling. He commissioned Raphael for making the four wall of his library, where Raphael painted the four branches of human knowledge, including The school of Atens. Raphael also painted his Portrait. He gave extensive commissions of paintings, sculpture, and architecture with a common theme of Christianity. After death of Julius, Michelangelo again commissioned and had to return to the same chapel where he had once painted the ceiling with high spirits of optimism, but now, he was old and filled with pessimism.
He made the alter wall. This was the era when patronage was at its peak.

To put in nutshell, patronage has always played a critical role in visual culture. It, on the one hand, provides an opportunity to create a remarkable art which centuries would remember, but on the other hand, it influenced the art. The paper examines different kind of patronages and its role and impact. The paper argues that patronage is a critical element in the understanding of art, and it is an area of study, which should be focused more along with the study of art.

\section{REFERENCES}

Baggaley, David. "Politics, Patronage \& Public Art." Circa, no. 54, 1990, pp. 31-33., www.jstor.org/ stable/25557571.

"How Did the Reformation Affect Art during and after the Sixteenth Century? - The Handy Art History Answer Book." How Did the Reformation Affect Art during and after the Sixteenth Century? - The Handy Art History Answer Book, 2020, www.papertrell.com/ apps/preview/The-Handy-Art-History-Answer-Book/ handy answer book/How-did-the-Reformation-affectart-during-and-after-the-sixt/001137026/content/ SC/52cb001682fad14abfa5c2e0_default.html.

Rookmaaker, H. R.. Christianity and art. Potchefstroomse Universiteit vir CHO, Instituut vir Reformatoriese Studie. 1985. pp. 47-52

Rubinstein, Nicolai. "Patronage, Art and Society in Renaissance Italy by F. W. Kent; Patricia Simons; J. C. Eade" "The Burlington Magazine." The Burlington Magazine, vol. 130, no. 1026, 1988, pp. 706-707., www. jstor.org/stable/883581.

Wilsey, John D., "The Impact of the Reformation on the Fine Arts" (2006). Faculty Publications and Presentations. Paper 175. http://digitalcommons.liberty. edu/sor_fac_pubs/175 